
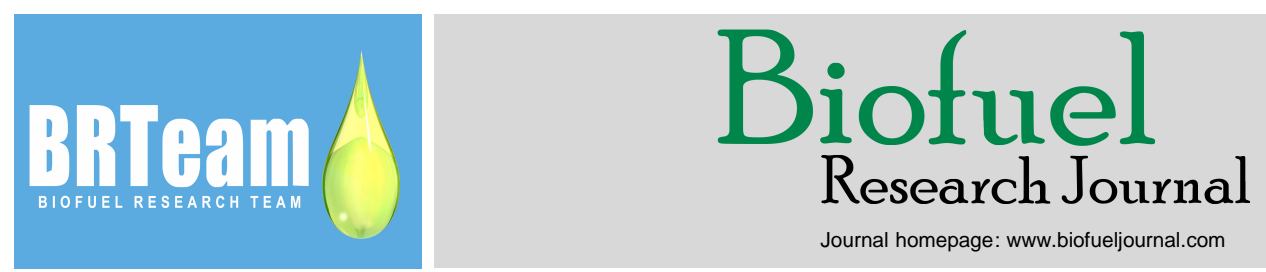

Original Research Paper

\title{
New insights into the application of microbial desalination cells for desalination and bioelectricity generation
}

\author{
Halima Alhimali ${ }^{1}$, Tahereh Jafary ${ }^{1}$, Abdullah Al-Mamun ${ }^{1, *}$, Mahad Said Baawain ${ }^{1}$, G. Reza Vakili-Nezhaad ${ }^{2}$ \\ ${ }^{1}$ Department of Civil and Architectural Engineering, Sultan Qaboos University, P.O. Box 33, Al-Khoud, 123, Muscat, Sultanate of Oman. \\ ${ }^{2}$ Department of Petroleum and Chemical Engineering, Sultan Qaboos University, P.O. Box 33, Al-Khoud, 123, Muscat, Sultanate of Oman.
}

\section{HIGHLIGHTS}

$>$ Ion behavior of three different salt solutions was studied in identical microbial desalination cells (MDCs).

$>\mathrm{Mg}^{2+}, \mathrm{Ca}^{2+}$, and $\mathrm{PO}_{4}{ }^{3-}$ were major ions resulting in scaling on cation exchange membrane.

$>$ Inorganic deposition and biofouling were more dominant on anion exchange membrane.

$>$ Back diffusion of $\mathrm{K}^{+}$from catholyte to liquid under desalination reduced MDC performance. $>$ Increasing bioelectricity generation will boost the rate of ions transportation.

\section{ARTICLE INFO}

\section{Article history:}

Received 25 October 2019

Received in revised form 20 November 2019

Accepted 22 November 2019

Available online 1 December 2019

\section{Keywords:}

Microbial desalination cell

Bioelectricity generation

Ion exchange membrane

Membrane fouling

Salt transfer

Ion diffusion

\section{GRAPHICAL ABSTRACT}

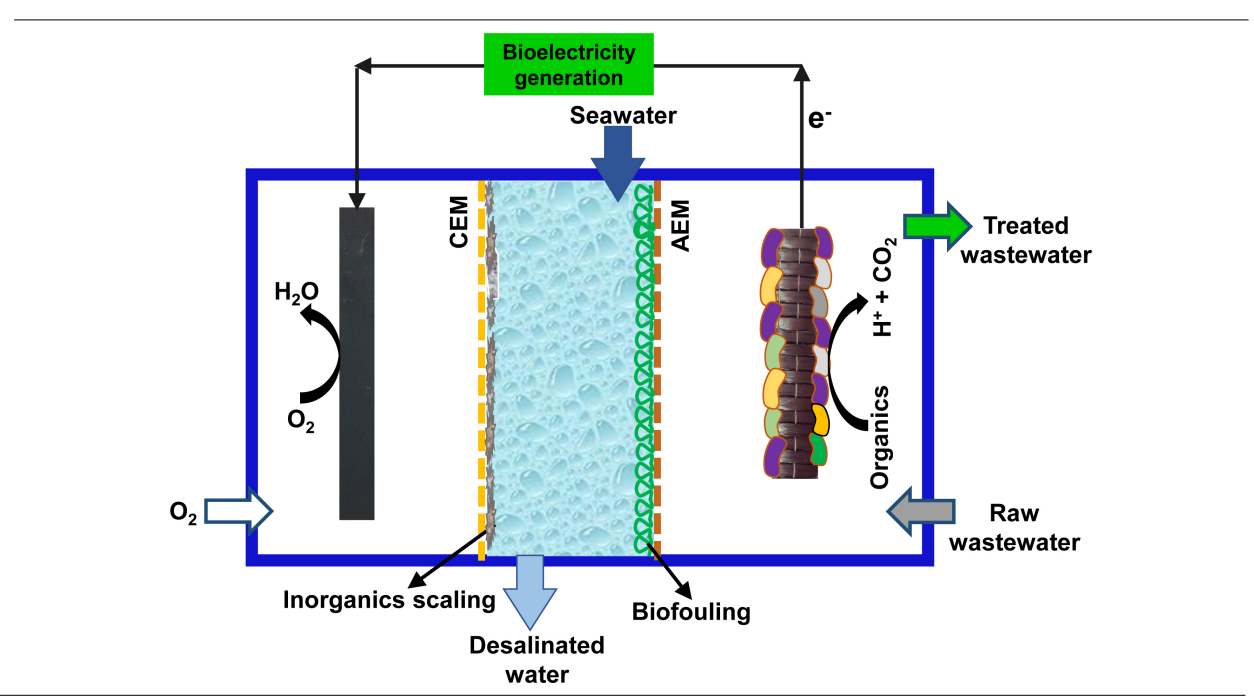

\begin{abstract}
Microbial desalination cell (MDC) is considered as a cost-effective substitution to the present energy-intensive desalination methods. Transfer of salt ions through ion exchange membranes towards the counter electrodes takes place through the utilization of self-generated bioelectricity and the concentration gradient. Ions transportation is one of the main challenges faced in MDCs to which less attention has been paid during the course of development. Therefore, new insights into the application of MDCs for efficient utilization of the generated bioelectricity for desalination are of high demand. In light of this, the present research thoroughly investigated the behavior of ions transportation and bioelectricity generation in three MDCs using three different salt solutions; $\mathrm{NaCl}$, synthetic and artificial seawater. The findings obtained suggested that the efficiency of ions transportation and fouling behavior were influenced by salt compositions and concentration of the salt solution. Multivalent ions (i.e. $\mathrm{Mg}^{2+}, \mathrm{Ca}^{2+}$, and $\mathrm{PO}_{4}{ }^{3-}$ ) were found more prone to precipitation on the CEM forming a scaling layer, whereas, inorganic deposition and biofouling development were more likely to happen on the AEM. This study also confirmed the occurrence of a significant back diffusion of $\mathrm{K}^{+}$from catholyte into desalination chamber. Such back diffusion could limit the use of potassium buffer in catholyte in real-scale applications. Moreover, the coefficients of salt transfer and ion diffusion were calculated using mathematical model and Excel solver in three running MDCs. Low salt transfer and ion diffusion coefficients values obtained for all three MDCs could explain the general low performance of MDCs. Further studies are required to optimize the salt transfer and ion diffusion coefficients to boost MDC performance in general; affecting their real-scale implementation.
\end{abstract}




\begin{tabular}{|ll|}
\hline Abbreviations & \\
AEM & Anion exchange membrane \\
CEM & Cation exchange membrane \\
COD & Chemical oxygen demand \\
SEM & Scanning electron microscopy \\
EC & Electrical conductivity \\
IEM & Ion exchange membrane \\
MDC & Microbial desalination cell \\
EDS & Energy dispersive spectrometry \\
IC & Ion chromatography \\
MDC-1 & MDC operated with NaCl \\
MDC-2 & MDC operated with synthetic seawater \\
MDC-3 & MDC operated with real seawater \\
\hline
\end{tabular}

\section{Introduction}

The rapid urbanization and economic growth around the world have created a high demand of freshwater and energy. Both water treatment technologies and required existing energy supplies are costly and unsustainable due to over utilization and inefficient methods (Sophocleous, 2004; Hertel and Liu, 2019). According to the World Health Organization, 20\% of the people around the world are living in scarce regions where they do not have access to clean water (Miller et al., 2015). This scarcity has made seawater desalination an essential contributor to supplying freshwater in many countries globally (Al Suleimani and Nair, 2000). Therefore; plenty of desalination plants have been constructed falling under three main categories; reverse osmosis, multi-stage flash, and multi-effect distillation (Ghaffour et al., 2015). As a concern, most of the commercial desalination plants are energy-intensive, employing thermal and membrane-based processes with around $2-15 \mathrm{kWh}$ energy consumption per cubic meter of water desalinated, and are thus associated with reduced process sustainability (Elimelech and Phillip, 2011; Peñate and García-Rodríguez, 2012). They also cause environmental deterioration because of the emission of greenhouse gases (Al Sajwani, 1998). In light of that, efforts have been put into developing more cost effective and eco-friendly alternatives to overcome the above-mentioned challenges (Al-Mamun and Baawain, 2015; Al-Mamun et al., 2017a)

Among the various solutions investigated, microbial desalination cells (MDCs) have attracted a great deal of attention owing to the sustainable and energy-effective nature of the technology (Chen et al., 2012; Forrestal et al., 2012). MDCs utilize bacteria as biocatalyst to convert chemical energy stored in organic wastes into electrical energy to drive the desalination process (anions moving towards anode while cations moving towards cathode through an ions exchange membrane) (Barua et al., 2018; Barua et al., 2019; Luo et al., 2012a; Zhao et al., 2019). The MDC concept has been explored rapidly and advanced configurations have been developed aiming at treatment of different salt contaminated water samples (Al-Mamun et al., 2018; Zuo et al., 2016). However, long-term operation of MDCs is still challenging because of the gradual drop of performance (triggered by biofouling and scaling of membranes) and the reduction in microbial community (biocatalyst) activity, necessitating more comprehensive in-depth investigations (Ping et al., 2013; Al Lawati et al., 2019).

Luo et al. (2012b) studied the performance of an MDC during an eightmonth operation and argued that current density, columbic efficiency, and desalination efficiency decreased over time. Further analysis showed that biofouling on the ion exchange membranes (IEMs) increased the resistance of the system, consequently reducing the ionic transformation and energy generation efficiency. Moreover, microbial communities became less active by the end of the operation as a result of imbalance $\mathrm{pH}$ and high internal resistance (Choi et al., 2011; Zhang et al., 2016). It is worth noting that the presence of multivalent cations like $\mathrm{Ca}^{+2}$ and $\mathrm{Mg}^{+2}$ could inhibit ions transportation through membranes and increase the membrane electrical resistance. This is mainly due to the precipitations of ions on the membrane leading to membrane scaling. Such precipitation of ions could decrease the whole reactor performance over time (Chen et al., 2013; Ma et al., 2015; Ebrahimi et al., 2018). Moreover, the rate of ions transportation through IEMs depends on the membrane microstructures. Such mobility of ions is significantly affected by ionic radius, ionic charge, and atomic mass (Luo et al., 2018). Generally, ions with the same valence but smaller radius migrate faster than those of larger radius (Chen et al., 2015). Zuo et al. (2013) observed the order of migration competition for the anions and cations in resins packed MDCs. The $\mathrm{SO}_{4}{ }^{2-}$ ions showed higher migration rates through an anion exchange membrane (AEM) compared to $\mathrm{NO}_{3}^{-}$and $\mathrm{Cl}^{-}$, while $\mathrm{Ca}^{2+}$ and $\mathrm{Mg}^{2+}$ recorded approximately the same migration rate, but higher than $\mathrm{NH}_{4}^{+}$and $\mathrm{Na}^{+}$ through a cation exchange membrane (CEM). Moreover, the selectively of membrane and molar conductivity would affect the order of ions migration. More specifically, the higher the molar conductivity, the higher the migration rate would be (Ho and Sirkar, 2012; Kamcev et al., 2018) Therefore, the types of anions and cations existing in saltwater could directly affect IEMs performance and consequently, the efficiency of MDC.

During the course of MDC development, AEM and CEM have been established as appropriate separators conducting selective ions transportations in the system (Strathmann, 2004; Li et al., 2011). Therefore, understanding the transportation behavior of ions existing in actual seawater through these membranes in MDCs is essential to bring the MDCs beyond lab-scale operations into the real world scenarios (Kamcev et al., 2018). However, despite plenty of studies carried out on decreasing electrical conductivity (EC) of $\mathrm{NaCl}$ solutions (representing seawater) in MDCs, fewer studies have been devoted to finding out the behavior of various ions transportation. This phenomenon plays an important role in the overall efficacy of bioelectricity generation and desalination process. Therefore, the current study was set to investigate the transportation behavior of major ions $\left(\mathrm{Cl}^{-}, \mathrm{F}^{-}, \mathrm{SO}_{4}^{2-}, \mathrm{PO}_{4}^{3-}, \mathrm{Na}^{+}, \mathrm{K}^{+}, \mathrm{Ca}^{2+}, \mathrm{Mg}^{2+}\right.$, etc. $)$ in an $\mathrm{MDC}$ using synthetic and real seawater. The electrical energy as the main driving force of desalination was provided through actual wastewater oxidation. More specifically, the study identified the quantity and rate of ions transportation in a three-chambered MDC utilizing three different salt solutions, i.e., pure $\mathrm{NaCl}$ solution, synthetic and real seawater, all having the same EC values. The amount of bioelectricity generation and organics removal by anodic biofilms as well as the changes observed in $\mathrm{pH}$ and $\mathrm{EC}$ for all the electrolytes were also recorded. The experimental and calculated values of the coefficients of membrane salt transfer and ions diffusion were determined as well for the MDC for the first time.

\section{Materials and Methods}

\subsection{MDC design and construction}

Three MDC reactors were designed and constructed by acrylic sheets and were operated for ions transport investigation (Fig. 1). Each reactor consisted of three chambers, i.e., anode, desalination and cathode chambers. The ultimate volumes of the anode, desalination and cathode chambers were $275,138,275 \mathrm{~mL}$, respectively. Rubber gaskets were placed between the chambers for a proper sealing. An AEM (AMI-7001S Membranes International Inc.) was placed between the desalination and anode chambers while a CEM (CMI-7000S Membranes International Inc.) was placed between the desalination and cathode chambers. The AEM and CEM were preconditioned by immersing in $5 \% \mathrm{NaCl}$ solution for $12 \mathrm{~h}$ before use for membrane hydration and expansion (Jafary et al., 2017). The total projected surface area of each membrane was $81 \mathrm{~cm}^{2}$. A carbon fiber of $81 \mathrm{~cm}^{2}$ in area was used as anode while a Pt-coated carbon cloth with an equal area was used as cathode $\left(0.5 \mathrm{mg} \mathrm{Pt} / \mathrm{cm}^{2}\right.$; Sainergy Tech, Inc). A stainless steel mesh was placed along the electrodes as current collector. The two electrodes were connected through a $1 \Omega$ external resistance by copper wires. A peristaltic pump (Cole Parmer, pump model, USA) with a flow rate of $70 \mathrm{~mL} / \mathrm{min}$ was used to recirculate the anolyte and catholyte from the recirculation containers $(1 \mathrm{~L})$ into the anode and cathode chambers. Four holes were drilled on the top of the recirculation containers for influent, effluent, sampling as well as $\mathrm{CO}_{2}$ exhaust (for the anolyte recirculation container) and oxygen sparging (for the catholyte recirculation container). The air was pumped into the catholyte using the air pump (AC-2000 model). 
A

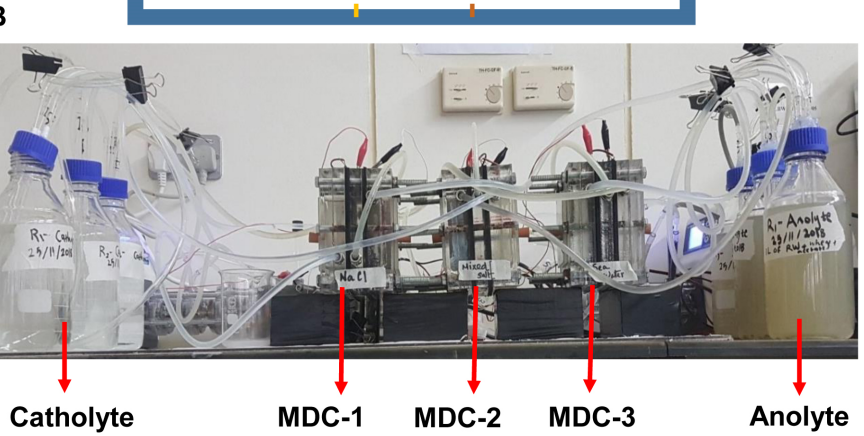

Fig. 1. (A) Schematic diagram of the designed MDC with different components, and (B) Experimental setup of the MDC system for investigation.

\subsection{Biofilm enrichment procedure}

Raw wastewater was collected from a wastewater treatment plant (Al-Ansab STP, Haya, Ghala, Oman) and was stored at $4^{\circ} \mathrm{C}$. The wastewater was used as the anolyte of the three reactors. Sodium acetate $1 \mathrm{~g} / \mathrm{L}$ was added to the anolyte for further biofilm enrichment. Phosphate buffer solution $(100 \mathrm{mM}, 9.34 \mathrm{~g} / \mathrm{L}$ of $\mathrm{K}_{2} \mathrm{HPO}_{4}, 6.3075 \mathrm{~g} / \mathrm{L}$ of $\left.\mathrm{KH}_{2} \mathrm{PO}_{4}\right)$ was used as the catholyte of the three reactors and was continuously aerated using the air pump. During biofilm enrichment, the middle chambers of all the three reactors were filled by $35 \mathrm{~g} / \mathrm{L}$ of $\mathrm{NaCl}$ solution. During the enrichment stage, the anolyte and catholyte were recirculated between the three MDCs, i.e., the effluent of each reactor was introduced into the subsequent reactor as influent. The flow rate of both anolyte and catholyte was $70 \mathrm{~mL} / \mathrm{min}$, which was maintained using a peristaltic pump (Masterflex, USA). During the enrichment stage, $\mathrm{pH}$, chemical oxygen demand (COD), and EC of all solutions were monitored at least once a day. Half of the anolyte was replaced with fresh raw wastewater and $1 \mathrm{~g} / \mathrm{L}$ of acetate weekly to avoid substrate inhibition during the enrichment stage. Potassium hydroxide solution $(2 \mathrm{M})$ was used to maintain the anolyte $\mathrm{pH}$ at around 7 during the experiment. External resistance was regulated (between 1 and $50 \Omega$ ) during the experiments to facilitate biofilm enrichment.

\subsection{MDC operation}

In order to investigate the ionic transport mechanisms, three different types of saltwater samples, i.e., pure $\mathrm{NaCl}$ solution, synthetic seawater, and real seawater were used in the desalination chambers of the three individual MDCs (Fig. 1). The first reactor (MDC-1) was operated with a monovalent solution of $35 \mathrm{~g} / \mathrm{L} \mathrm{NaCl}$. The second reactor (MDC-2) was operated with synthetic seawater while the third reactor (MDC-3) was operated using real seawater obtained from the Al-Seeb Cornish (Muscat, Oman). The synthetic salt solutions in the MDC-1 and MDC-2 were adjusted to have similar EC values as real seawater $(55.4 \mathrm{mS} / \mathrm{cm})$. The systems were operated in the recirculation batch mode from the individual anolyte and catholyte tanks with similar compositions stated previously (See Section 2.2). Each experiment was run in triplicate and the average value of the three runs were reported. Table 1 shows the ionic characteristics of the saltwater samples analyzed.
Table 1.

Ionic compositions of the three saltwater samples, the catholyte, and the anolyte (i.e. domestic wastewater) used in this study.

\begin{tabular}{|c|c|c|c|c|c|}
\hline \multirow[b]{2}{*}{$\begin{array}{l}\text { Ions } \\
\text { concentration } \\
(\text { ppm) }\end{array}$} & \multicolumn{3}{|c|}{ Saltwater in desalination chamber } & \multirow{2}{*}{$\begin{array}{c}\text { Catholyte } \\
\begin{array}{c}\text { Phosphate } \\
\text { buffer }\end{array}\end{array}$} & \multirow{2}{*}{$\begin{array}{c}\text { Anolyte } \\
\begin{array}{c}\text { domestic } \\
\text { wastewater }\end{array}\end{array}$} \\
\hline & $\begin{array}{l}\text { Pure NaCl } \\
\text { solution } \\
\text { (MDC-1) }\end{array}$ & $\begin{array}{l}\text { Synthetic } \\
\text { seawater } \\
\text { (MDC-2) }\end{array}$ & $\begin{array}{c}\text { Real } \\
\text { seawater } \\
\text { (MDC-3) }\end{array}$ & & \\
\hline Chloride & 16057.424 & 16778.177 & 18125.530 & 22.475 & 232.039 \\
\hline Fluoride & - & 26.555 & 0.873 & - & 0.343 \\
\hline Sulphate & - & 10.016 & 2210.473 & - & 0.760 \\
\hline Bromide & - & - & 77.085 & - & 82.095 \\
\hline Nitrate & - & - & 39.379 & - & - \\
\hline Phosphate & - & - & - & 7293.370 & 12.415 \\
\hline Sodium & 14080 & 13380 & 12200 & 680 & - \\
\hline Potassium & 132 & 580 & 435 & 5560 & - \\
\hline Magnesium & 0.781 & 1267 & 1328 & 0.279 & - \\
\hline Calcium & 0.717 & 388.3 & 389.6 & 7.305 & - \\
\hline
\end{tabular}

\subsection{Analyses}

Anions were analyzed for all three saltwater solutions using an ion chromatography (IC) system. The concentration of cations was measured using the flame photometric and atomic absorption spectrometer methods. The analyses were carried out on salt samples taken every two days to examine the ions transportation behavior and their removal rates. In addition, the $\mathrm{EC}$ of the anolyte, catholyte, and salt solutions were measured daily using an EC meter while the $\mathrm{pH}$ was measured using the a $\mathrm{pH}$ meter (HI5522, Hanna, USA). The COD of the anolyte samples was determined daily using the standard method. The voltage $(\mathrm{E}, \mathrm{mV})$ was recorded every five minutes using a data acquisition system (Omega, UK) over a one $\Omega$ external resistor $\left(\mathrm{R}_{\mathrm{e}}\right)$. The current (I, A) was calculated using the Ohm's law equation. Finally, the used membranes were characterized by scanning electron microscopy (SEM) and energy dispersive spectrometry (EDS) to examine membrane biofouling and scaling as well as to inspect the precipitated elements on the surface of the membranes (Ebrahimi et al. 2018).

\subsection{Salt mass balance}

Mass balance equations (Eqs. 1-3) were used to measure the coefficients of salt transfer and ion diffusion for the membranes utilized in the MDC system. The method of measurements was adopted from Ping et al. (2014):

$$
\begin{gathered}
\frac{d C_{\text {salt }, m}}{d t}=D_{\text {salt }}\left(C_{\text {salt.in }}-C_{\text {salt }, m}\right)-d\left(C_{\text {salt }, m}-C_{\text {salt }, a}\right) \\
-d\left(C_{\text {salt }, m}-C_{\text {salt }, c}\right)-\frac{I_{M D C}}{F . V_{\text {salt }}}
\end{gathered}
$$

$D_{\text {salt }}=\frac{Q_{\text {salt }}}{V_{\text {salt }}}$

$d=\frac{A_{\text {membrane }}\left(a_{d}\right)}{V_{a} b}$

where, $C_{\text {salt, in }}$ is the initial salt concertation, $C_{\text {salt }, m}, C_{\text {salt }, a}, C_{\text {salt, },}$ denote the salt concentrations in the desalination, anode, and cathode chambers (mol of salt $/ \mathrm{L}), D_{\text {salt }}$ stands for the salt dilution rate $\left(\right.$ day $\left.^{-1}\right)$, d is the coefficient of salt transfer (day $\left.{ }^{-1}\right), I_{M D C}$ is the produced current (A) in the MDC, $F$ denotes the Faraday's constant (A.day/mol), $V_{\text {salt }}$ stands for the volume of desalination chamber in $\mathrm{L}, \mathrm{Q}_{\text {salt }}$ is the flow rate of the salt solution., $A_{\text {membran }}$ is the membrane surface area, $a_{d}\left(\mathrm{~m}^{2} / \mathrm{s}\right)$ represents the coefficient of ion diffusion, $V_{a}$ is the volume $\left(\mathrm{m}^{3}\right)$ of anode chamber, and $\mathrm{b}$ denotes the membrane thickness $(\mathrm{m})$. The diffusion coefficient is an important 
parameter in MDCs as it describes ions transportation rate during the operation. This was calculated from the experimental results of the MDC-1 by using the Equations 1, 2, and 3. The $\mathrm{NaCl}$ concentration was analyzed on the day 1, 3, 6 , and 9 of the operation. Excel "Solver" tool was used to calculate the optimized values of salt transfer coefficient, i.e., $\mathrm{d}^{\left(\mathrm{d}^{-1}\right)}$ using Equation 1 and the diffusion coefficient, i.e., $\mathrm{a}_{\mathrm{d}}\left(\mathrm{m}^{2} / \mathrm{s}\right)$ using Equation 3 .

\section{Results and Discussion}

\subsection{Biofilm enrichment}

The three MDCs were connected in series (in a recirculation batch mode being fed from a $10 \mathrm{~L}$ container of raw wastewater with $1 \mathrm{~g} / \mathrm{L}$ of acetate as substrate) to enrich the biofilm on anode during the first month of biofilm enrichment. $\mathrm{NaCl}$ solution $(35 \mathrm{~g} / \mathrm{L})$ was used in the desalination chamber in batch mode during the biofilm development period in all three reactors. The external resistance $\left(R_{e x t}\right)$ was changed between 1 and $50 \Omega$ during the enrichment stage; i.e., $1 \Omega\left(0-10^{\text {th }}\right.$ day), $50 \Omega\left(11-16^{\text {th }}\right.$ day $)$, and $1 \Omega\left(17^{\text {th }}\right.$ until the end). The current generation during the biofilm enrichment was recorded. In the first ten days of the enrichment $\left(R_{e x t}=1 \Omega\right)$, the current generation was very low due to low density of microbial population on the anode surface. During these first ten days, very low $R_{e x t}$ was used to overcome the activation losses which is a common practice in microbial fuel cell research (Al-Mamun et al., 2017b). Then, the $R_{\text {ext }}$ was switched to $50 \Omega$ on day 11 because the enriched biofilm was able to overcome the activation losses. The MDC reactors were operated with $50 \Omega$ from the $11^{\text {th }}$ to the $16^{\text {th }}$ day of enrichment. However, all the MDC reactors achieved a maximum current generation during 12-14 days of the enrichment period, showing the optimum time for electroactive biofilm development (Al-Mamun et al., 2016).

After reaching the maximum current, the current generation profile showed a gradual drop. This was mainly due to the drop of $\mathrm{pH}$ in the anolyte. The $\mathrm{pH}$ drop was due to proton accumulation in the anolyte, which negatively affected the biofilm and ultimately the current generation (Nikhil et al., 2016). Therefore, the effects of proton accumulation in the anolyte was diminished by setting back $R_{e x t}$ to low external resistance at $1 \Omega$ to facilitate an easy flow of electrons from the anode to the cathode. Such higher flow of electrons enhanced the migration of ions from the desalination chamber to anode and cathode chambers, which ultimately increased the EC decrement (Chen et al., 2013). The migrated $\mathrm{Cl}^{-}$ions neutralized the accumulated proton in the anolyte and reduced the effect of $\mathrm{pH}$ drop. All three MDCs were then operated individually using separate recirculation tanks (Fig 1. B) to investigate the other biochemical parameters.

\subsection{Effect of salt compositions on desalination performance}

After a successful biofilm enrichment, the three MDC reactors were operated using three different salt solutions in the desalination chambers. The $\mathrm{EC}$ of all the salt solutions were initially set at $55.4 \mathrm{mS} / \mathrm{cm}$, which was equal to the $\mathrm{EC}$ value of the real seawater. However, the ions composition of the three salt solutions and their concentrations were different. The operation was carried out for $10 \mathrm{~d}$ with four cycles of anolyte refreshment in the recirculation tanks. Figure 2A-C shows the performance of the MDCs in terms of current generation, EC decrement, and $\mathrm{pH}$ changes of the anolyte in the studied reactors. In an MDC system, the trend of current generation demonstrates the performance of anodic biofilm in degrading organics while EC reduction represents the migration of salt ions from the desalination chamber to the anolyte and catholyte chambers, and finally, $\mathrm{pH}$ reduction in the anolyte is the result of the accumulation of $\mathrm{H}^{+}$and the migration of $\mathrm{Cl}^{-}$(Luo et al., 2010; Wen et al., 2012). pH reduction could adversely affect the performance of the anodic biofilm, which could ultimately affect the whole system performance (Luo et al., 2012c). The anolyte refreshment in all the three MDCs was performed once the $\mathrm{pH}$ level dropped to the acidic level (Haavisto et al., 2019). The acidity of the anolyte increased due to accumulation of $\mathrm{H}^{+}$generated by the biodegradation of organics and the migration of anions (mostly $\mathrm{Cl}^{-}$) on the anode as described by Wen et al. (2012). Such pH drops in the anodic media could adversely influence both current generation and desalination rate (Davis et al., 2013). All the MDCs under investigation showed similar trends of current generation $(\max 1.5 \pm 0.5 \mathrm{~mA}), \mathrm{EC}$ reduction, and $\mathrm{pH}$ fluctuation which were expected due to similar anolyte and catholyte used in all three systems. However, MDC-1 (operated with $\mathrm{NaCl}$ solution) showed the highest EC reduction (66.5\%), while MDC-3 (operated with real seawater) showed the lowest EC reduction (62.1\%) (Fig. 2D) over the first ten days of the operation. The results obtained indicated that the monovalent ions moved faster than the multivalent ions as the synthetic and real seawater contained different composition of multivalent ions $\left(\mathrm{Ca}^{2+}, \mathrm{Mg}^{2+}\right.$, etc. $)$. The findings were in agreement with those of Luo et al. (2012a) who reported higher salt removal rates with the a pure $\mathrm{NaCl}$ solution in comparison with the mixed salt solution.

For all the three MDCs, there was a relationship between the $\mathrm{pH}$ trend and $\mathrm{EC}$ decrement. Changes in anolyte $\mathrm{pH}$ beyond the acceptable range for microbial growth could strongly influence the biofilm activity, which could in turn limit the MDC performance in terms of current generation and desalination rate (Qu et al., 2012). As a result, the anolyte solution was refreshed regularly once the $\mathrm{pH}$ and eventually the current started to drop significantly.

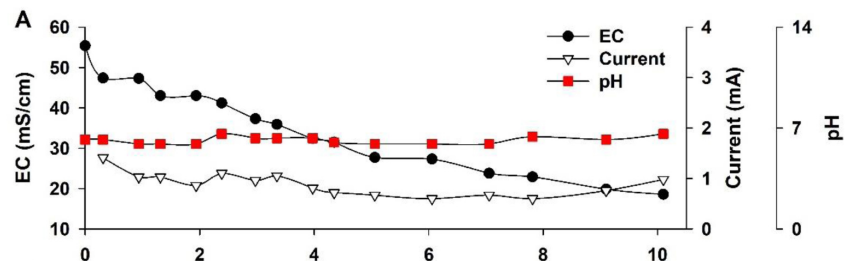

B
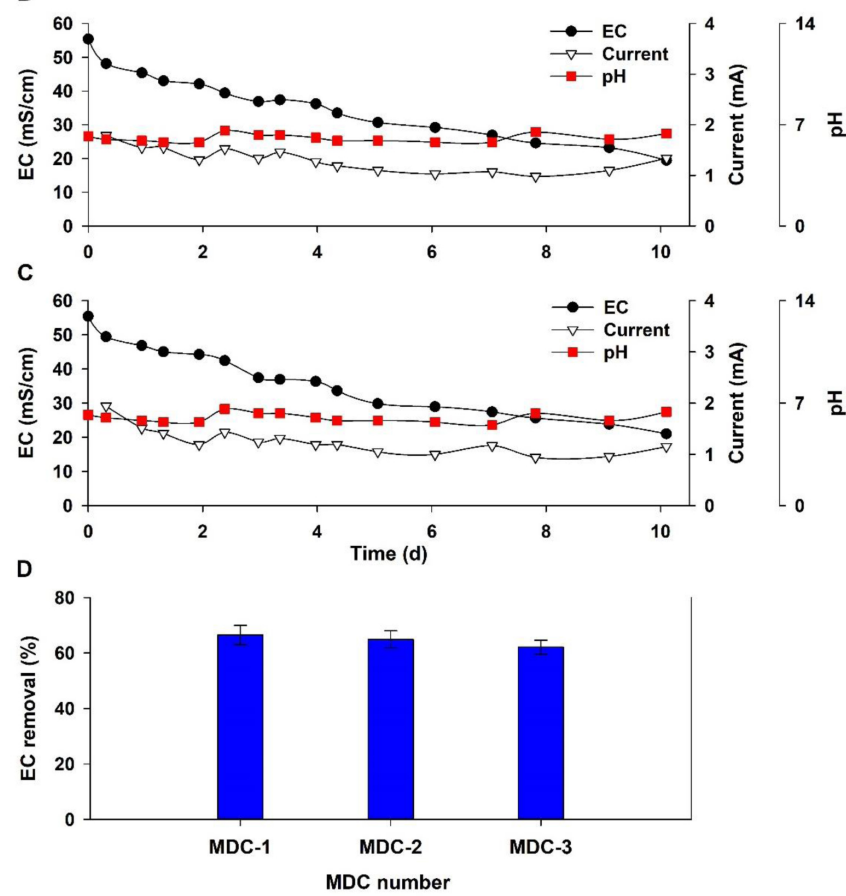

Fig. 2. EC of the salt solutions, $\mathrm{pH}$ of the anolyte, and current generation during $10 \mathrm{~d}$ of operation in (A) MDC-1 operated with $\mathrm{NaCl}$, (B) MDC-2 operated with synthetic seawater, (C) MDC-3 operated with real seawater (dash lines indicate the anolyte refreshment stages), and (D) EC decrement (\%) for MDC-1, MDC-2, MDC-3.

\subsection{Ions transport across the membranes in $M D C$ s}

The compositions of the three different salt solutions were investigated elaborately using IC for anions $\left(\mathrm{Cl}^{-}, \mathrm{F}^{-}, \mathrm{SO}_{4}{ }^{2-}, \mathrm{PO}_{4}{ }^{3-}\right.$, etc. $)$, while flame photometric and atomic absorption spectrometer were used for looking into cations $\left(\mathrm{Na}^{+}, \mathrm{K}^{+}, \mathrm{Ca}^{2+}, \mathrm{Mg}^{2+}\right.$, etc.). The analyses were carried out on the samples taken from the catholyte recirculation tanks and desalination chambers every two days. The investigation of the ions transport behavior was performed based on decreasing ions mass in the desalination chamber and corresponding increment of ions mass in the catholyte. The analysis of 
ions mass changes in the anolyte was not feasible due to equipment limitation caused by the interference of the proteins contained in the wastewater samples.

Figures 3, 4, and 5 show the transportation behavior of ions across the membranes in the desalination and cathode chambers of the three MDCs. Figures $3 \mathrm{~A}, 4 \mathrm{~A}$, and $5 \mathrm{~A}$ present that the concentration of $\mathrm{Cl}^{-}, \mathrm{Na}^{+}, \mathrm{Ca}^{2+}, \mathrm{Mg}^{2+}$ ions reduced in the desalination chambers by the migration of ions from desalinating liquid to the other chambers. Such ionic migration happened due to concentration gradients and electrochemical attraction over time. Similar ionic migration was also observed by Zuo et al. (2013) who used a resin packed MDC system. A significant concentration of $\mathrm{K}^{+}$ions was present in the buffering liquid utilized as catholyte in the present MDC operation. The $\mathrm{K}^{+}$ back diffused from the catholyte to the desalination chamber and accumulated gradually in the liquid being desalinated, which ultimately increased the ions concentration in this chamber. Such accumulation of $\mathrm{K}^{+}$negatively affected the desalination efficiency of the MDC. None of the previous studies reported the phenomenon of $\mathrm{K}^{+}$accumulation in the desalination chamber (Luo et al., 2012a; Post et al., 2009). Such ionic accumulation and back diffusion could be prevented by using a proper approach for $\mathrm{pH}$ control rather than using buffering agents.

Figures 3B, 4B, and 5B show the changes in $\mathrm{Na}^{+}, \mathrm{K}^{+}, \mathrm{Mg}^{2+}$, and $\mathrm{PO}_{4}{ }^{3-}$ concentrations in the catholyte during the whole operation period. The results obtained revealed that the concentrations of $\mathrm{Na}^{+}$and $\mathrm{Mg}^{2+}$ increased, while the concentration of $\mathrm{PO}_{4}{ }^{3-}$ was almost unchanged, and the concentration of $\mathrm{K}^{+}$ gradually decreased in the catholyte during the operational time.

A
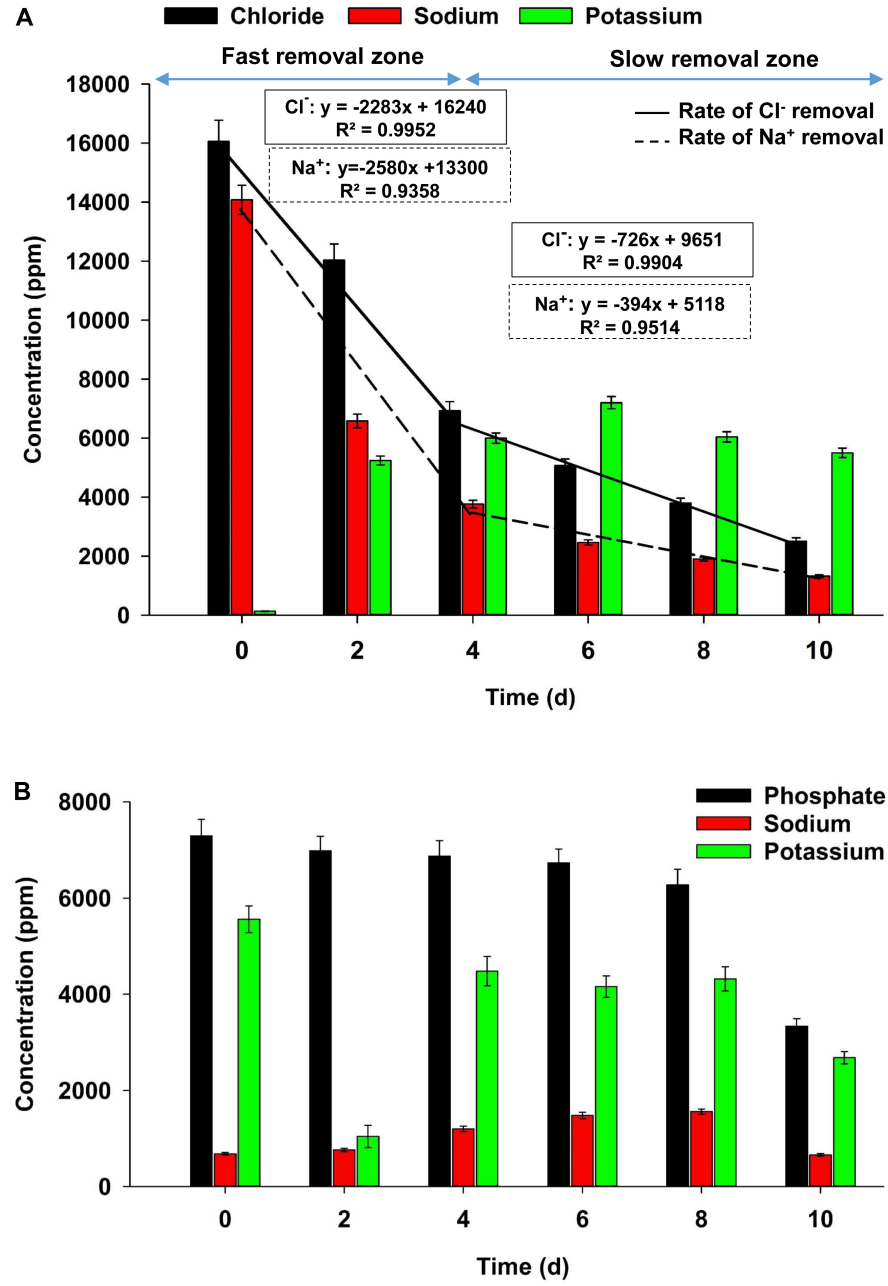

Fig. 3. Ions concentration in, (A) desalination chamber, and (B) catholyte over the operation period in MDC-1.
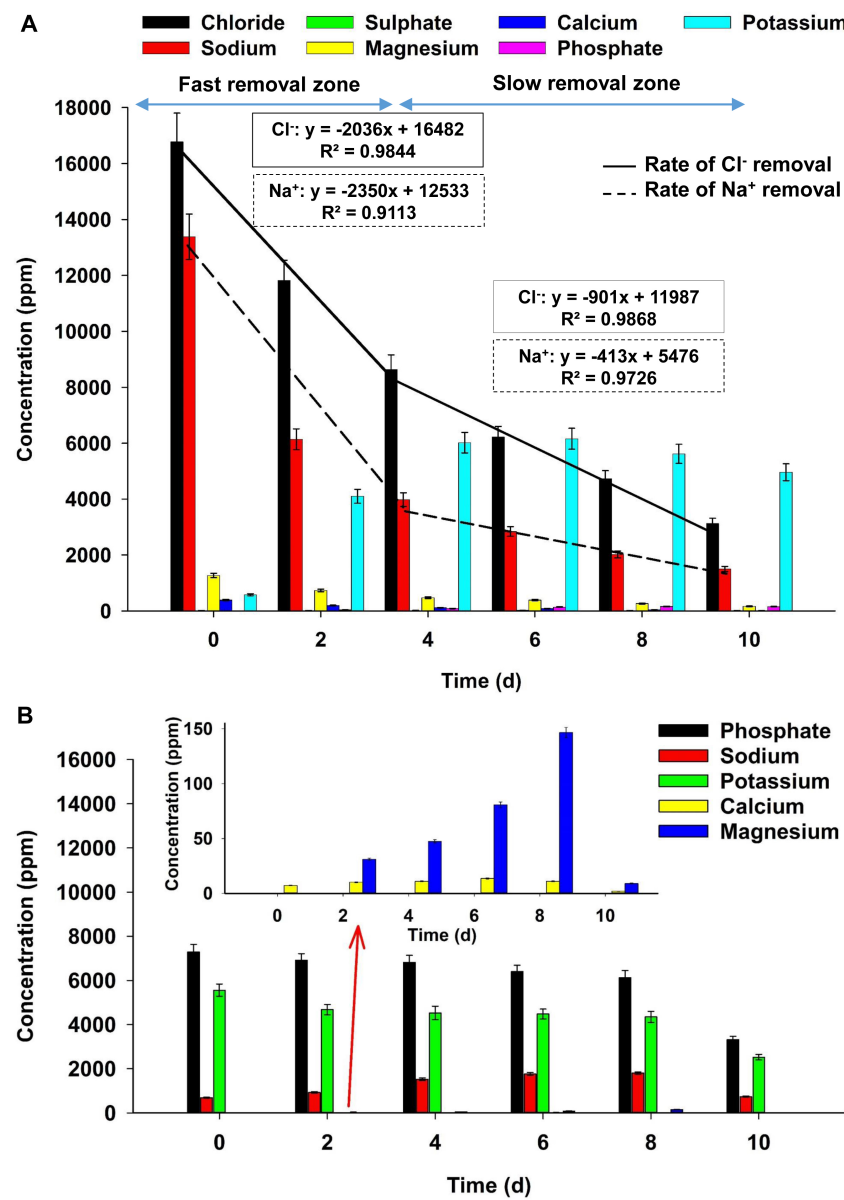

Fig. 4. Ions concentration in, (A) desalination chamber, and (B) catholyte over the operation period in MDC-2.

Table 2 summarizes the removal efficiency of ions from the three different types of liquids being desalinated during $10 \mathrm{~d}$ of operation. The results indicated that the highest $\mathrm{Na}^{+}$removal efficiency achieved was $91 \%$, when the pure $\mathrm{NaCl}$ solution was used. While moderate $\mathrm{Na}^{+}$removal efficiency $(89 \%)$ and low $\mathrm{Na}^{+}$removal efficiency $(85 \%)$ were observed when using the synthetic and real seawater samples, respectively. The slightly lower removal efficiency of $\mathrm{Na}^{+}$with the synthetic and rea seawater was due to the competition in ions migration from the complex mixture of seawater. Nevertheless, in the case of pure $\mathrm{NaCl}$ and real seawater, the $\mathrm{Cl}^{-}$removal efficiency was the same (84\%), while it was slightly lower at $81 \%$ in the case of synthetic seawater. The efficiency of $\mathrm{Mg}^{2+}$ removal varied between $79-87 \%$, while the $\mathrm{Ca}^{2+}$ removal fluctuated between $86-96 \%$. In both cases of $\mathrm{Mg}^{2+}$ and $\mathrm{Ca}^{2+}$ removal, the efficiencies were higher $(87 \%$ and $96 \%$ ) with the synthetic seawater than with the real seawater. The high removal rates of $\mathrm{Mg}^{2+}$ and $\mathrm{Ca}^{2+}$ with the synthetic seawater could be ascribed to the controlled composition of ions without any biological impurities and other scale-forming chemicals.

Table 2.

Removal efficiency $(\%)$ of the ions from the liquids being desalinated during the $10-\mathrm{d}$ operation.

\begin{tabular}{|c|c|c|c|c|c|c|}
\hline \multirow{2}{*}{ MDC No. } & \multirow{2}{*}{$\begin{array}{c}\text { Liquid being } \\
\text { desalinated }\end{array}$} & \multicolumn{5}{|c|}{ Removal efficiency (\%) } \\
\hline & & $\mathrm{Cl}^{-}$ & $\mathrm{SO}_{4}{ }^{2-}$ & $\mathrm{Na}^{+}$ & $\mathrm{Mg}^{2+}$ & $\mathrm{Ca}^{2+}$ \\
\hline MDC-1 & Pure $\mathrm{NaCl}$ solution & 84 & - & 91 & - & - \\
\hline MDC-2 & Synthetic seawater & 81 & - & 89 & 87 & 96 \\
\hline MDC-3 & Real seawater & 84 & 72 & 85 & 79 & 86 \\
\hline
\end{tabular}


A
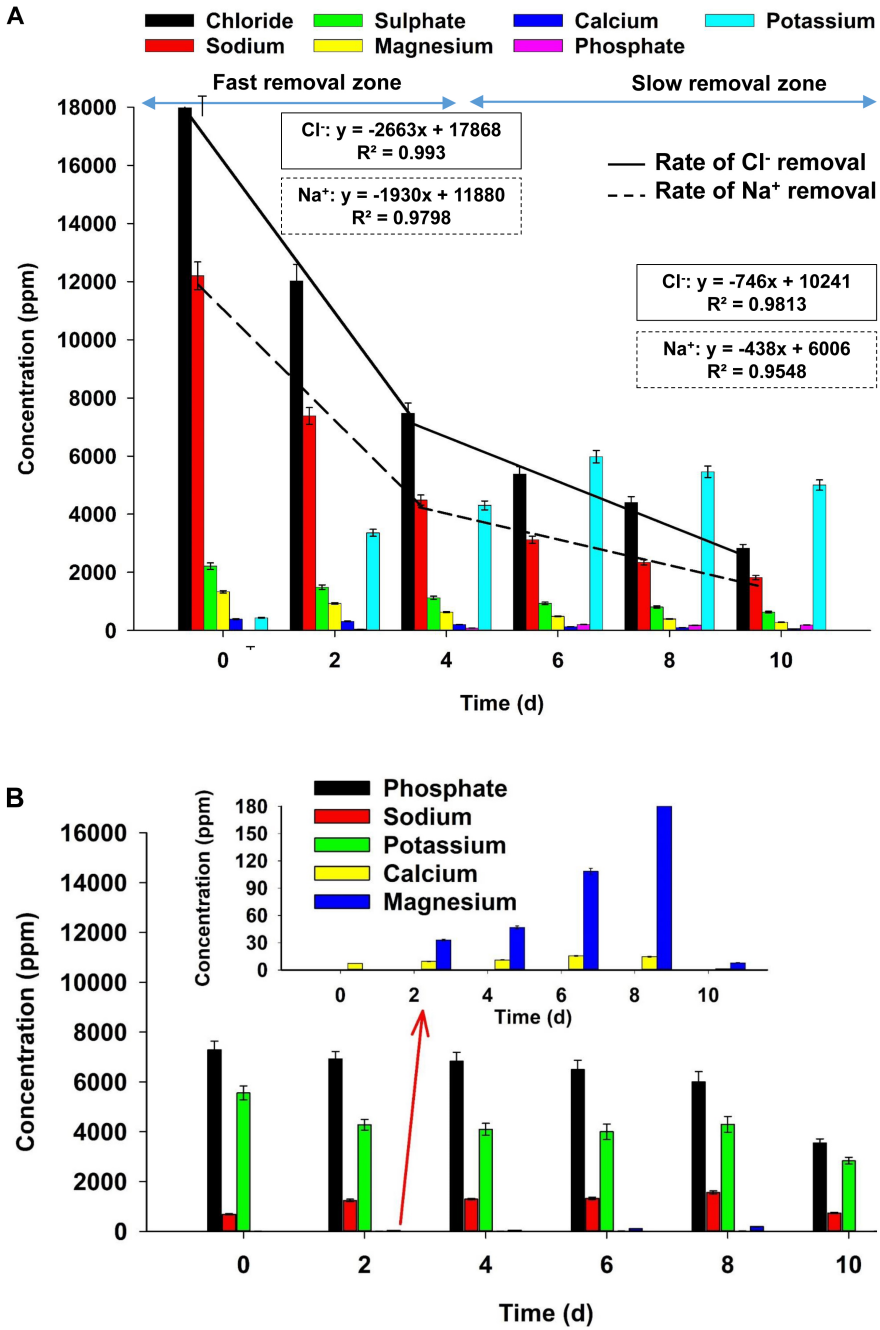

Fig. 5. Ions concentration in, (A) desalination chamber and (B) catholyte over the operation period in MDC-3.

During the 10-day batch operation, the linear trends of $\mathrm{Na}^{+}$and $\mathrm{Cl}^{-}$removal from the investigated samples in the three MDCs followed a similar pattern having two clear zones, i.e., the zone of fast rate removal during the $0-4^{\text {th }}$ days and the zone of slow rate removal during the $4-10^{\text {th }}$ days of operation (Fig. 3A, 4A, 5A). The linear graphs and the slopes of the corresponding linear equations are included in Figures 3A, 4A, and 5A. The linear equation in Figure 3A shows that the rate of $\mathrm{Cl}^{-}$removal from the pure $\mathrm{NaCl}$ solution stood at 2283 $\mathrm{ppm} / \mathrm{d}$ during the $0-4^{\text {th }}$ days, while it dropped to $726 \mathrm{ppm} / \mathrm{d}$ during the $4-10^{\text {th }}$ days of operation. Similarly, the rate of $\mathrm{Na}^{+}$removal dropped from $2580 \mathrm{ppm} / \mathrm{d}$ to $394 \mathrm{ppm} / \mathrm{d}$ at the end of the first 4 days of operation. Figures $4 \mathrm{~A}$ and $\mathbf{5 A}$ demonstrate the declines in $\mathrm{Cl}^{-}$removal rate from $2036 \mathrm{ppm} / \mathrm{d}$ to $901 \mathrm{ppm} / \mathrm{d}$ for the synthetic seawater and from $2663 \mathrm{ppm} / \mathrm{d}$ to $746 \mathrm{ppm} / \mathrm{d}$ for the real seawater at the end of the $4^{\text {th }}$ day of operation. Moreover, the rate of $\mathrm{Na}^{+}$removal dropped from $2350 \mathrm{ppm} / \mathrm{d}$ to $413 \mathrm{ppm} / \mathrm{d}$ for the synthetic seawater, while it dropped from $1930 \mathrm{ppm} / \mathrm{d}$ to $438 \mathrm{ppm} / \mathrm{d}$ for the real seawater at the end of the $4^{\text {th }}$ day of operation (Fig. 4A and 5A). In both cases of pure $\mathrm{NaCl}$ solution and synthetic seawater, the rate of $\mathrm{Na}^{+}$removal was higher than that of $\mathrm{Cl}^{-}$during the initial stage (i.e., 0-4 ${ }^{\text {th }}$ d) of operation. While, for all cases, the estimated rate of $\mathrm{Cl}^{-}$ removal was higher than that of $\mathrm{Na}^{+}$during the later stage (i.e., 4-10 $0^{\text {th }} \mathrm{d}$ ) of operation. However, during the entire operational period with the real seawater, the rate of $\mathrm{Cl}^{-}$removal was higher than that of $\mathrm{Na}^{+}$. The maximum $\mathrm{Cl}^{-}$removal achieved was $2663 \mathrm{ppm} / \mathrm{d}$ when using real seawater due to the highest initial $\mathrm{Cl}^{-}$concentration in the solution, while the maximum $\mathrm{Na}^{+}$removal was achieved at $2580 \mathrm{ppm} / \mathrm{d}$ while using pure $\mathrm{NaCl}$ solution due to its highest initial $\mathrm{Na}^{+}$concentration $v s$. the other solutions. The results obtained also showed that for both $\mathrm{Na}^{+}$and $\mathrm{Cl}^{-}$, the maximum ions removal rates were achieved when the highest initial ions concentration was employed. These findings proved the importance of initial ion concentration and consequently, the concentration gradient as the main contributor to the rate of ions transportation. Similar findings were also reported by Ping et al (2015).

The higher concentration of ions in the desalination chamber reduced the negative effect of the increased distance between the electrodes by the addition of the middle chamber in the investigated MDCs. It in fact played an important role in reducing the MDC internal resistance (Jafary et al., 2018). In both cases of synthetic and real seawater samples, about $79 \%$ of $\mathrm{Mg}^{2+}$ and $86 \%$ of $\mathrm{Ca}^{2+}$ were removed. However, the MDC operated with real seawater showed the lowest ion transportation efficiency compared to the ones operated with the pure $\mathrm{NaCl}$ solution and synthetic seawater. This phenomenon could be explained by the complex dynamics of seawater. More specifically, the presence of other multivalent ions in seawater must have created higher ions competition as well faster membrane fouling, scaling, pore blocking, and back diffusion (Luo et al., 2012a).

In general, the mass of the transported ions from the desalination chamber should be approximately equal to the mass of accumulated ions in the anolyte and catholyte. However, as presented in Figures 3, 4, and 5, not all the mass of the cations transported from the desalination chamber was recovered in the catholyte. This slightly low recovery of cations in the catholyte could be explained by the identified precipitation of $\mathrm{Ca}^{2+}$ and $\mathrm{Mg}^{2+}$ on the membrane, subsequently hampering the performance of the membrane transportation (Cruz et al., 2018). These precipitations and scaling were further investigated by characterizing the ions deposited on the surface of the membrane using SEM and EDS at the end of operation (See Section 3.4).

\subsection{Investigation of membrane fouling and scaling}

After four months of operation, the AEM and CEM of the MDC-3 were taken to investigate fouling and scaling phenomena. Figure 6 depicts the SEM images while Figure 7 presents the EDS images of unused and fouled AEM and CEM in the case of real seawater as liquid under desalination.

The SEM images showed the physical deposition of multi-layered fouling and crystal materials on the surface of the membranes (Fig. 6), while the EDS images showed the distribution of the deposited ions on both sides of the membranes (Fig. 7). The SEM images indicated a dense biofouling layers on the anode side of the AEM (Fig. 6C) and ligh biofouling layers on its desalination side (Fig. 6B). Such biofouling layer grew due to the direct exposure of the AEM to wastewater used as media in the anode chamber. The EDS images showed a high deposition of sulphate $\left(\mathrm{SO}_{4}{ }^{2-}\right)$ on the desalination side of the AEM (Fig. 7B), while magnesium, aluminum, and silicon were deposited mostly on the anode side of the AEM (Fig. 7C). Other elements such as oxygen, chloride, fluoride, and carbon shown in the EDS images of the AEM were mostly the inherent components of the AEM polymer. The aluminum and silicon depositions over the AEM (at the anode side) were mostly originated from the wastewater, while the $\mathrm{SO}_{4}{ }^{2-}$ and $\mathrm{Mg}^{2+}$ depositions over the AEM (at the desalination side) were mostly originated from seawater.

A coarse crystalline aggregate was observed on the cathode side of the CEM (Fig. 7F) and a granular crystal deposition was detected on the desalination side of the CEM (Fig. 7E). The scaling layer on the desalination side of the CEM composed mainly of magnesium phosphate $\left(\mathrm{Mg}^{2+}\right.$ from seawater and $\mathrm{PO}_{4}{ }^{3-}$ from catholyte), while on the cathode side of the CEM, it composed mainly of calcium phosphate $\left(\mathrm{Ca}^{2+}\right.$ from seawater and $\mathrm{PO}_{4}{ }^{3-}$ from catholyte). The distribution of elements, i.e., oxygen, sodium, sulphate, fluoride, and carbon shown in the EDS images of the CEM could mostly be ascribed to the inherent components of the CEM polymer. The results obtained confirmed that $\mathrm{Mg}^{2+}$ was deposited before transportation through the membrane and $\mathrm{Ca}^{2+}$ was deposited after transportation through the membrane. This might be due to the differenct ionic radiuses of these two cations. Therefore, the scaling on both sides of the CEM (Fig. 7E and F) was mainly due to the deposition of multivalent ions such as $\mathrm{Mg}^{2+}, \mathrm{Ca}^{2+}$, and $\mathrm{PO}_{4}{ }^{3-}$, which were abundant in seawater and cathoyte. 

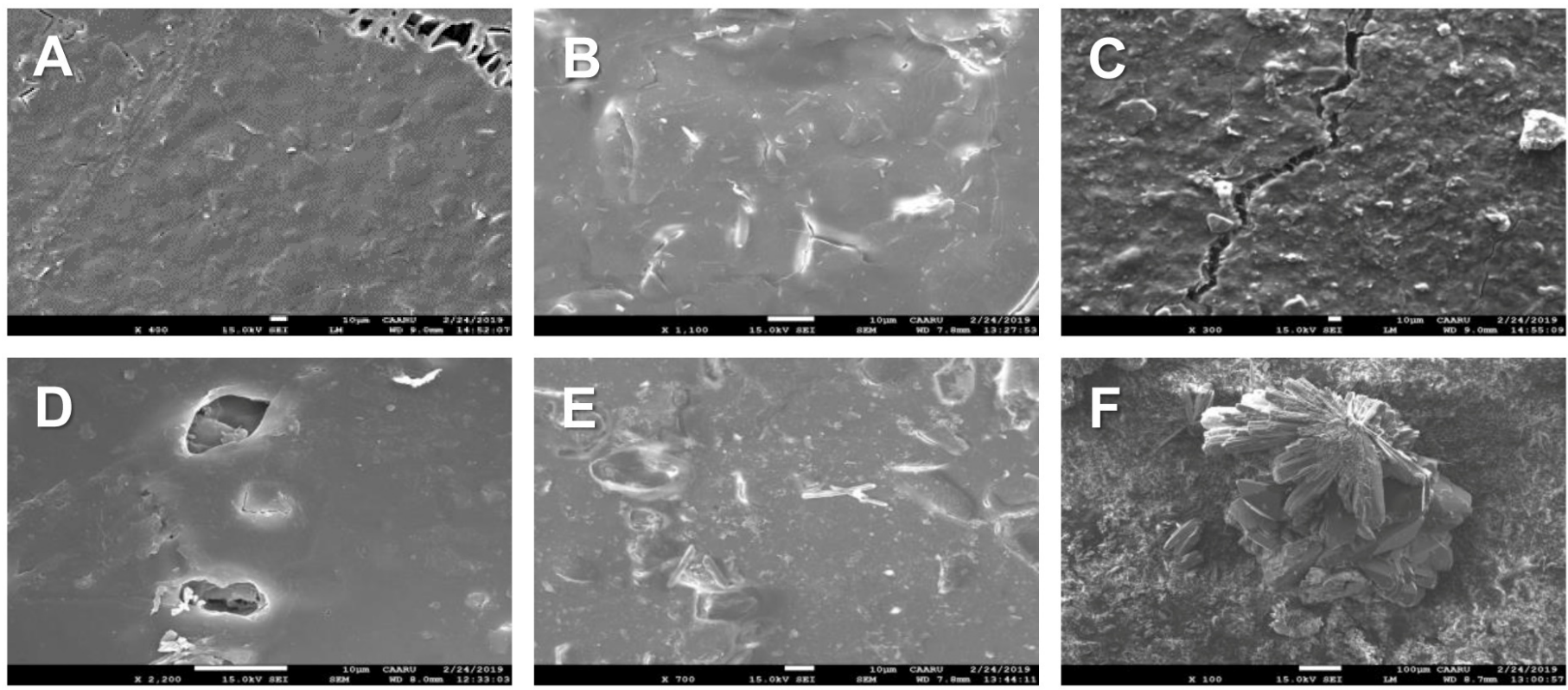

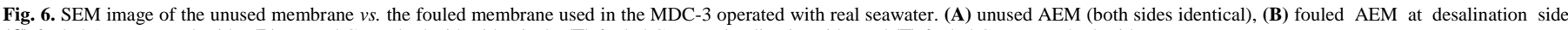
(C) fouled AEM at anode side, (D) unused CEM (both sides identical), (E) fouled CEM at desalination side, and (F) fouled CEM at cathode side.

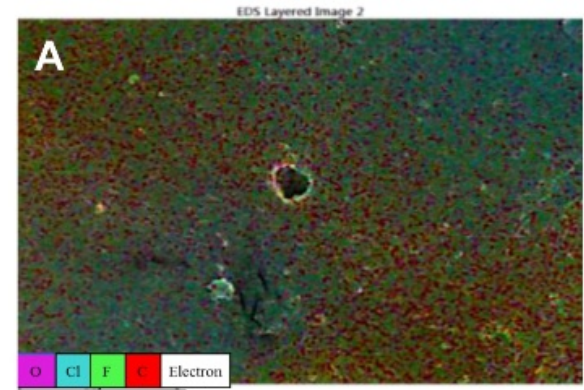

$25 \mu \mathrm{m}$

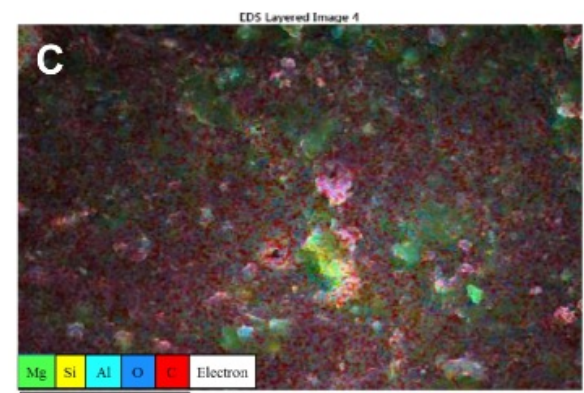

$25 \mu \mathrm{m}$

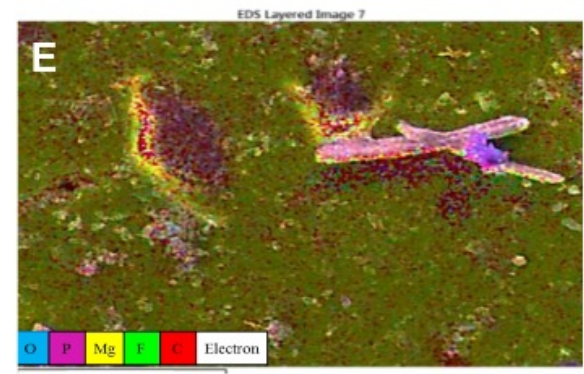

$25 \mu \mathrm{m}$

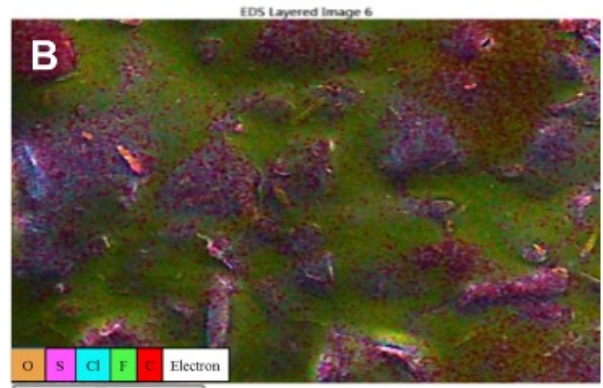

$25 \mu \mathrm{m}$

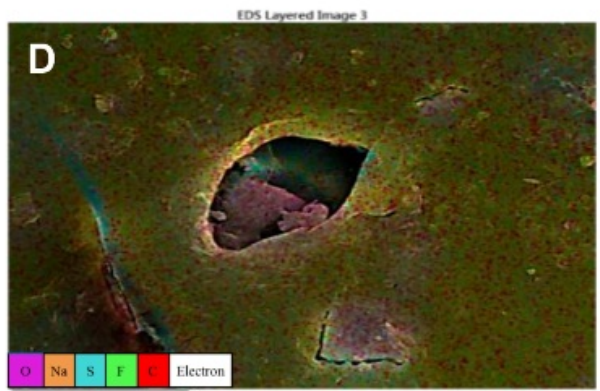

$25 \mu \mathrm{m}$

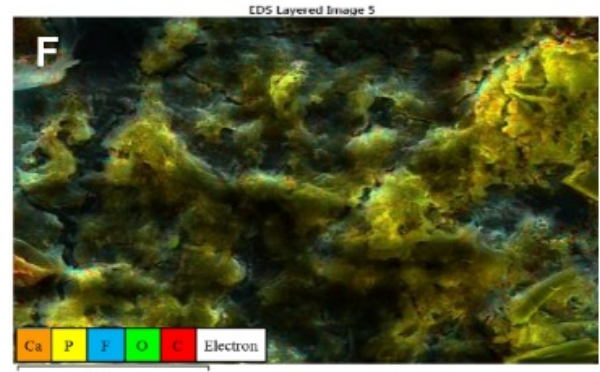

$25 \mu \mathrm{m}$

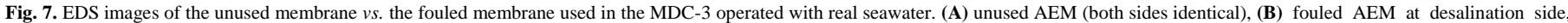
(C) fouled AEM at anode side, (D) unused CEM (both sides same), (E) fouled CEM at desalination side, and (F) fouled CEM at cathode side. 
Figure 8 summarizes the main components of the scaling and biofouling materials on the AEM and CEM used in the present MDC system.

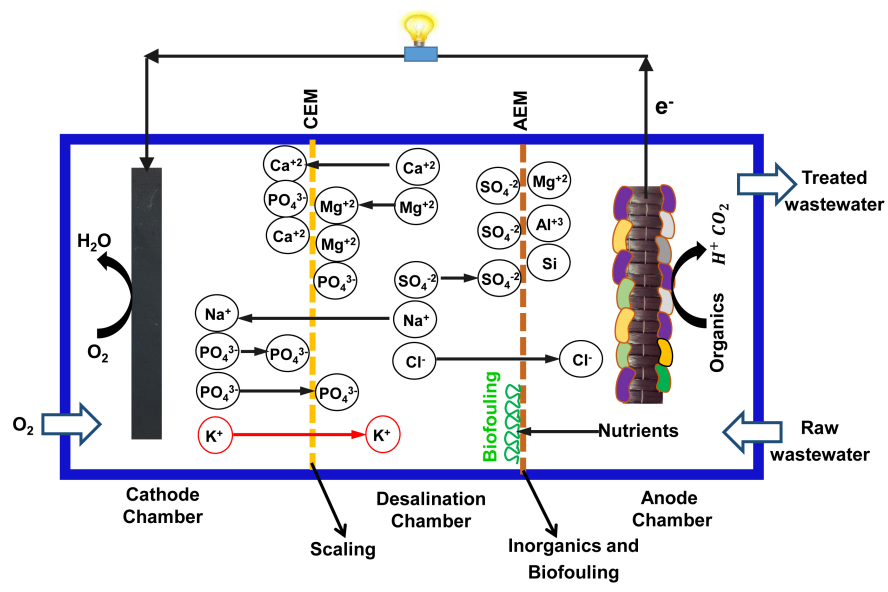

Fig. 8. Graphical representation of the major components of the fouling and scaling materials on the AEM and CEM used in the MDC.

The dissimilar behavior observed in the transportation of $\mathrm{Mg}^{2+}$ and $\mathrm{Ca}^{2+}$ was likely due to the difference in their radius and mobility. $\mathrm{Ca}^{2+}$ with a small radius $(0.349 \mathrm{~nm})$ possessed a higher mobility across the CEM than $\mathrm{Mg}^{2+}$ with a large radius $(0.429 \mathrm{~nm})$. However, the multivalent ions such as $\mathrm{Mg}^{2+}, \mathrm{Ca}^{2+}$, and $\mathrm{PO}_{4}{ }^{3-}$ showed a higher tendency to deposit on the CEM compared to the monovalent ions such as $\mathrm{Cl}^{-}, \mathrm{K}^{+}$, and $\mathrm{Na}^{+}$. Similar findings were also observed by Jacobson et al. (2011) and Luo et al. (2012a), however, they only reported the amount of transported ions from the liquid under desalination, but overlooked the amount of deposition on membranes. Such scaling tendency of multivalent ions could exert negative effects on system performance as well. In the MDC investigated herein, the scaling associated with the precipitation of metallic phosphate on the CEM (i.e., $\mathrm{Ca}_{3}\left(\mathrm{PO}_{4}\right)_{2}$ on cathode side and $\mathrm{Mg}_{3}\left(\mathrm{PO}_{4}\right)_{2}$ on desalination side) was mainly due to concentration polarization, ion over-saturation, and ion interception; very common phenomena in commercial IEMs. Such scaling problems limit the utilization of phosphate buffer as a $\mathrm{pH}$ neutralizing agent in catholyte (Strathmann, 2004). However, scaling could be prevented by selecting an appropriate filtration technique, regulating $\mathrm{pH}$ and ions oversaturation, as well as applying anti-scalents and electrochemical mechanisms such as reverse electrode polarity (Baker, 2012; Cruz et al., 2018; Koók et al., 2019). On the other hand, biofouling layer has been found as a major concern for the AEM, declining the quality of desalinated water as the result of the diffused nutrients from the anode to the desalination chamber (Mikhaylin and Bazinet, 2016), while also reducing the transportation of ions by growing biofilm on the membrane (Ping et al., 2016). The growth of biofouling layer mostly depends on the types of microorganisms and their growth factors such as temperature, $\mathrm{pH}$, as well as the abundance of organic and inorganic nutrients. Biofouling could be prevented by in-situ cleaning of membranes with air bubbles or any other physical forces. Further studies would be required to investigate the possibility of adding anti-fouling agents in MDCs as also used in the electrodialysis systems.

\subsection{Mass balance of ions transported through membranes}

Modeling could provide a better understanding of the transportation behavior of ions in an MDC system. The mass balance equations (Eqs. 1-3) were used to calculate the coefficients of salt transfer and ion diffusion for major ions in salt solutions, i.e., $\mathrm{Na}^{+}$and $\mathrm{Cl}^{-}$. Table 3 tabulates the analytical concentrations of $\mathrm{Na}^{+}$and $\mathrm{Cl}^{-}$ions as major ions in all the chambers of the three studied MDCs as well as the generated currents at every two-day intervals during the 10-d operational cycle. The coefficient of salt transfer of $0.829,0.5$, and $0.4 \mathrm{~d}^{-1}$ were obtained for $\mathrm{Na}^{+} / \mathrm{Cl}^{-}$ions in MDC-1, MDC-2 and MDC-3, respectively. Moreover, ion diffusion coefficient of $1.46 \times 10^{-10}, 0.88 \times 10$ -10 , and $0.707 \times 10^{-10} \mathrm{~m}^{2} / \mathrm{s}$ were calculated (for $\mathrm{Na}^{+} / \mathrm{Cl}^{-}$) in MDC-1, MDC-2 and MDC-3, respectively. The trend of the results was in good agreement with the experimental data reported in Table 2. The lower salt transfer and ion diffusion coefficients in MDC-2 and MDC-3 compared to MDC-1 were due to the presence of other multivalent ions in the synthetic and real seawater which must have created a higher rate of ions competition as well faster membrane fouling, scaling, pore blocking, and back diffusion (Luo et al., 2012a).

Table 3.

Coefficients of salt transfer and ion diffusion calculated by using experimental data.

\begin{tabular}{|c|c|c|c|c|c|c|}
\hline \multirow{2}{*}{ MDC No. } & \multirow{2}{*}{ Experimental data } & \multicolumn{5}{|c|}{ Time (d) } \\
\hline & & 2 & 4 & 6 & 8 & 10 \\
\hline \multirow{4}{*}{ MDC-1 } & $\mathrm{C}_{\text {salt }}(\mathrm{mol} / \mathrm{L})$ & 0.318 & 0.182 & 0.128 & 0.097 & 0.065 \\
\hline & $\mathrm{C}_{\text {anolyte }} \times 10^{-5}(\mathrm{~mol} / \mathrm{L})$ & 0.113 & 0.144 & 0.052 & 0.036 & 0.035 \\
\hline & $\mathrm{C}_{\text {catholyte }}(\mathrm{mol} / \mathrm{L})$ & 0.326 & 0.123 & 0.056 & 0.024 & 0.025 \\
\hline & Current $(\mathrm{mA})$ & 0.86 & 0.81 & 0.6 & 0.6 & 0.98 \\
\hline \multirow{4}{*}{ MDC-2 } & $\mathrm{C}_{\text {salt }}(\mathrm{mol} / \mathrm{L})$ & 0.307 & 0.216 & 0.155 & 0.115 & 0.079 \\
\hline & $\mathrm{C}_{\text {anolyte }} \times 10^{-5}(\mathrm{~mol} / \mathrm{L})$ & 0.139 & 0.089 & 0.068 & 0.042 & 0.045 \\
\hline & $\mathrm{C}_{\text {catholyte }}(\mathrm{mol} / \mathrm{L})$ & 0.315 & 0.094 & 0.049 & 0.036 & 0.023 \\
\hline & Current (mA) & 1.31 & 1.27 & 1.03 & 0.98 & 1.34 \\
\hline \multirow{4}{*}{ MDC-3 } & $\mathrm{C}_{\text {salt }}(\mathrm{mol} / \mathrm{L})$ & 0.332 & 0.204 & 0.145 & 0.115 & 0.079 \\
\hline & $\mathrm{C}_{\text {anolyte }} \times 10^{-5}(\mathrm{~mol} / \mathrm{L})$ & 0.172 & 0.128 & 0.059 & 0.028 & 0.044 \\
\hline & $\mathrm{C}_{\text {catholyte }}(\mathrm{mol} / \mathrm{L})$ & 0.209 & 0.126 & 0.059 & 0.034 & 0.023 \\
\hline & Current (mA) & 1.19 & 1.19 & 1.00 & 0.94 & 1.15 \\
\hline MDC No. & Calculated data & & & & & \\
\hline \multirow{2}{*}{ MDC-1 } & \multicolumn{3}{|c|}{ Salt transfer coefficient $\left(\mathrm{d}^{-1}\right)$} & \multicolumn{3}{|l|}{0.829} \\
\hline & \multicolumn{3}{|c|}{ Ion diffusion coefficient $\left(\mathrm{m}^{2} / \mathrm{s}\right)$} & \multicolumn{3}{|c|}{$1.46 \times 10^{-10}$} \\
\hline \multirow{2}{*}{ MDC-2 } & \multicolumn{3}{|c|}{ Salt transfer coefficient $\left(\mathrm{d}^{-1}\right)$} & \multicolumn{3}{|l|}{0.5} \\
\hline & \multicolumn{3}{|c|}{ Ion diffusion coefficient $\left(\mathrm{m}^{2} / \mathrm{s}\right)$} & \multicolumn{3}{|c|}{$0.88 \times 10^{-10}$} \\
\hline \multirow{2}{*}{ MDC-3 } & \multicolumn{3}{|c|}{ Salt transfer coefficient $\left(\mathrm{d}^{-1}\right)$} & \multicolumn{3}{|l|}{0.4} \\
\hline & \multicolumn{3}{|c|}{ Ion diffusion coefficient $\left(\mathrm{m}^{2} / \mathrm{s}\right)$} & \multicolumn{3}{|c|}{$0.707 \times 10^{-10}$} \\
\hline
\end{tabular}

The coefficient of ion diffusion for $\mathrm{NaCl}$ has been reported in other systems like electrodialysis using different types of IEMs (Table 4). However, to the best of our knowledge, these information are reported herein for the first time. Low salt transfer and ion diffusion coefficients of the MDCs proved low and slow ion diffusion through the membranes which could be explained as the main reason to low MDC performance; affecting its real-scale implementation. Noteworthy, these values were affected by different MDC parameters, such as generated current and properties of membranes (thickness and surface area), which are accounted for in Equation 3. For instance, by increasing the current from $1 \mathrm{~mA}$ to $3 \mathrm{~mA}$ in the system, the coefficient of ion diffusion could increase by two times. It should be noted that the efficiency of current generation in an MDC is quite low due to the high internal resistance imposed by the middle salt chamber. Therefore, the application of appropriate strategies to increase current production (bioelectricity generation) while decreasing the internal resistance could significantly increase the ionic diffusion rate. Ideally, Ping et al. (2015) reported that one mole of electrons could transfer two molarequivalents of ions from the liquid under desalination to the counter electrolytes (anolyte and catholyte). They also found a correlation between MDC current with internal resistance and junction potential (Ping et al. 2015). However, the junction potential was more related to ion properties such as ions transport number and ion charge. Therefore, further studies would be required to understand the factors, which could affect and maximize the diffusion coefficients of salts in MDCs. 
Table 4.

Diffusion coefficient of $\mathrm{NaCl}$ salt using different types of membranes in electrodialysis as reported in the literatures $v s$. those obtained in the MDC used in the present study.

\begin{tabular}{lccl}
\hline Membrane Types & Ion & $\begin{array}{c}\text { Diffusion } \\
\text { coefficient }\left(\mathbf{m}^{2} / \mathbf{s}\right)\end{array}$ & Reference \\
\hline $\begin{array}{l}\text { Anion and cation } \\
\text { exchange polymer } \\
\text { membranes with binder } \\
\text { and woven matrix (AMI- } \\
7001 \text { \& CMI -7000) }\end{array}$ & $\mathrm{Na}^{+} \& \mathrm{Cl}^{-}$ & $0.88 \times 10^{-10}$ & Present Study (MDC-2) \\
\hline $\begin{array}{l}\text { Nafion-450 } \\
\mathrm{Na}^{+} \& \mathrm{Cl}^{-}\end{array}$ & $5.80 \times 10^{-11}$ & Korngold (1984) \\
$\begin{array}{l}\text { Nafion-117 } \\
\begin{array}{l}\text { AMX (a type of polymer } \\
\text { membrane carrying } \\
\text { quaternary ammonium } \\
\text { bases) }\end{array}\end{array}$ & $\mathrm{Na}^{+}$ & $7.80 \times 10^{-11}$ & Goswami et al. (2001) \\
$\begin{array}{l}\text { AFN (a type of polymer } \\
\text { membrane carrying } \\
\text { quaternary ammonium } \\
\text { bases) }\end{array}$ & $\mathrm{Cl}^{-}$ & $5.10 \times 10^{-11}$ & Elattar et al. (1998) \\
\hline
\end{tabular}

\section{Conclusions}

Self-generated bioelectricity and concentration gradient are responsible forces transfering salt ions across membranes in MDCs. The present study looked into the transportation behavior of major ions using three different salt solutions. The findings obtained demonstrated that the efficiency of ions transportation and fouling behavior were influenced by salt compositions and concentration in the liquids being desalinated. Multivalent ions were found more prone to precipitation on the CEM forming a scaling layer, whereas, inorganic deposition and biofouling development were more likely to happen on the AEM. This study also confirmed the occurrence of a significant back diffusion of $\mathrm{K}^{+}$from catholyte into the liquid under desalination. Such back diffusion could limit the use of potassium buffer in catholyte. That is why the conventional three-chambered MDC design in which potassium phosphate buffer is used is not proper in terms of cost-efficiency, eco-friendliness, and sustainability. Exploring new configurations and operational methods could improve the system performance while overcoming the challenges faced in ions transportation and membrane fouling. Moreover, based on the findings of the present study, it could be concluded that the general low performance of MDCs; affecting their real-scale implementation is ascribed to their low salt transfer and ion diffusion coefficients. Therefore, efforts should be directed towards MDC optimization in terms of electrolyte, membrane, and configuration to boost salt transfer and ion diffusion coefficients. Through future improvements, MDCs could well serve as ecofriendly and energy efficient alternatives to the currently-used energy-intensive desalination methods.

\section{Acknowledgments}

The authors wish to extend their appreciation to the Sultan Qaboos University (SQU), Muscat, Oman, for the financial support provided through His Majesty's Trust Fund (SR/ENG/CAED/17/01) in collaboration with the University of Alberta, Edmonton, Canada.

\section{References}

[1] Al-Mamun, A., Ahmad, W., Baawain, M.S., Khadem, M., Dhar, B.R., 2018. A review of microbial desalination cell technology: Configurations, optimization and applications. J. Cleaner Prod. 183, 458-480.

[2] Al-Mamun, A., Baawain, M.S., 2015. Accumulation of intermediate denitrifying compounds inhibiting biological denitrification on cathode in Microbial Fuel Cell. J. Environ. Health Sci. Eng. 13(1), 81

[3] Al-Mamun, A., Baawain, M.S., Egger, F., Al-Muhtaseb, A.a.H., Ng, H.Y., 2017a. Optimization of a baffled-reactor microbial fuel cell using autotrophic denitrifying bio-cathode for removing nitrogen and recovering electrical energy. Biochem. Eng. J. 120, 93-102.
[4] Al-Mamun, A., Baawain, M.S., Dhar, B.R., Kim, I.S., 2017b. Improved recovery of bioenergy and osmotic water in an osmotic microbial fuel cell using micro-diffuser assisted marine aerobic biofilm on cathode. Biochem. Eng. J. 128, 235-242.

[5] Al-Mamun, A., Lefebvre, O., Baawain, M., Ng, H., 2016. A sandwiched denitrifying biocathode in a microbial fuel cell for electricity generation and waste minimization. Int. J. Environ. Sci. Technol. 13(4), 1055-1064.

[6] Al Lawati, M.J., Jafary, T., Baawain, M.S., Al-Mamun, A., 2019. A mini review on biofouling on air cathode of single chamber microbial fuel cell; prevention and mitigation strategies. Biocatal. Agric. Biotechnol. 101370 .

[7] Al Sajwani, T.b.M.A., 1998. The desalination plants of Oman: past present and future. Desalination. 120(1-2), 53-59

[8] Al Suleimani, Z., Nair, V.R., 2000. Desalination by solar-powered reverse osmosis in a remote area of the Sultanate of Oman. Appl Energy. 65(1-4), 367-380.

[9] Baker, R.W., 2012. Membrane technology and applications. John Wiley \& Sons.

[10] Barua, S., Zakaria, B.S., Al-Mamun, A., Dhar, B.R., 2018. Anodic performance of microbial electrolysis cells in response to ammonia nitrogen. Journal of Environmental Engineering and Science J. Environ. Eng. Sci. 14(1), 37-43

[11] Barua, S., Zakaria, B.S., Chung, T., Hai, F.I., Haile, T., Al-Mamun, A., Dhar, B.R., 2019. Microbial electrolysis followed by chemical precipitation for effective nutrients recovery from digested sludge centrate in WWTPs. Chem. Eng. J. 361, 256-265.

[12] Chen, S., Luo, H., Hou, Y., Liu, G., Zhang, R., Qin, B., 2013. Comparison of the removal of monovalent and divalent cations in the microbial desalination cell. Front. Environ. Sci. Eng. 9(2), 317-323.

[13] Chen, X., Liang, P., Wei, Z., Zhang, X., Huang, X., 2012. Sustainable water desalination and electricity generation in a separator coupled stacked microbial desalination cell with buffer free electrolyte circulation. Bioresour. Technol. 119, 88-93.

[14] Choi, M.-J., Chae, K.-J., Ajayi, F.F., Kim, K.-Y., Yu, H.-W., Kim, C.-W., Kim, I.S., 2011. Effects of biofouling on ion transport through cation exchange membranes and microbial fuel cell performance. Bioresour. Technol. 102(1), 298-303.

[15] Cruz, C., Cisternas, L.A., Kraslawski, A., 2018. Scaling problems and control technologies in industrial operations: Technology Assessment. Sep. Purif. Technol. 207, 20-27.

[16] Davis, R.J., Kim, Y., Logan, B.E., 2013. Increasing desalination by mitigating anolyte ph imbalance using catholyte effluent addition in a multi-anode bench scale microbial desalination cell. ACS Sustainable Chem. Eng. 1(9), 1200-1206.

[17] Ebrahimi, A., Najafpour, G.D., Kebria, D.Y., 2018. Performance of microbial desalination cell for salt removal and energy generation using different catholyte solutions. Desalination. 432, 1-9.

[18] Elattar, A., Elmidaoui, A., Pismenskaia, N., Gavach, C., Pourcelly, G., 1998. Comparison of transport properties of monovalent anions through anion-exchange membranes. J. Membr. Sci. 143(1-2), 249261.

[19] Elimelech, M., Phillip, W.A., 2011. The future of seawater desalination: energy, technology, and the environment. Science. 333(6043), 712-717

[20] Forrestal, C., Xu, P., Ren, Z., 2012. Sustainable desalination using a microbial capacitive desalination cell. Energy Environ. Sci. 5(5), 7161-7167.

[21] Ghaffour, N., Bundschuh, J., Mahmoudi, H., Goosen, M.F., 2015. Renewable energy-driven desalination technologies: A comprehensive review on challenges and potential applications of integrated systems. Desalination. 356, 94-114.

[22] Goswami, A., Acharya, A., Pandey, A., 2001. Study of self-diffusion of monovalent and divalent cations in Nafion-117 ion-exchange membrane. J. Phys. Chem. B. 105(38), 9196-9201.

[23] Haavisto, J.M., Lakaniemi, A.-M., Puhakka, J.A., 2019. Storing of exoelectrogenic anolyte for efficient microbial fuel cell recovery. Environ. Technol. 40(11), 1467-1475 
[24] Hertel, T., Liu, J., 2019. Implications of water scarcity for economic growth, Economy-Wide Modeling of Water at Regional and Global Scales. Springer.

[25] Ho, W., Sirkar, K., 2012. Membrane handbook. Springer Science \& Business Media.

[26] Jacobson, K.S., Drew, D.M., He, Z., 2011. Use of a liter-scale microbial desalination cell as a platform to study bioelectrochemical desalination with salt solution or artificial seawater. Environ. Sci. Technol. 45(10), 4652-4657

[27] Jafary, T., Aljlil, S.A., Alam, J., Ghasemi, M., 2017. Effect of the membrane type and resistance load on the performance of the microbial fuel cell: a step ahead of microbial desalination cell establishment. J. Jpn. Inst. Energy. 96(9), 346-351.

[28] Jafary, T., Daud, W.R.W., Aljlil, S.A., Ismail, A.F., Al-Mamun, A., Baawain, M.S., Ghasemi, M., 2018. Simultaneous organics, sulphate and salt removal in a microbial desalination cell with an insight into microbial communities. Desalination. 445, 204-212.

[29] Kamcev, J., Paul, D.R., Manning, G.S., Freeman, B.D., 2018. Ion Diffusion Coefficients in Ion Exchange Membranes: Significance of Counterion Condensation. Macromolecules. 51(15), 5519-5529.

[30] Koók, L., Bakonyi, P., Harnisch, F., Kretzschmar, J., Chae, K.-J., Zhen, G., Kumar, G., Rózsenberszki, T., Tóth, G., Nemestóthy, N., 2019. Biofouling of membranes in microbial electrochemical technologies: Causes, characterization methods and mitigation strategies. Bioresour. Technol. 279, 327-338.

[31] Korngold, E., 1984. Electrodialysis-membranes and mass transport. Synthetic membrane processes, 191-220.

[32] Li, W.-W., Sheng, G.-P., Liu, X.-W., Yu, H.-Q., 2011. Recent advances in the separators for microbial fuel cells. Bioresour. Technol. 102(1), 244252.

[33] Luo, H., Jenkins, P.E., Ren, Z., 2010. Concurrent desalination and hydrogen generation using microbial electrolysis and desalination cells. Environ. Sci. Technol. 45(1), 340-344.

[34] Luo, H., Xu, P., Jenkins, P.E., Ren, Z., 2012a. Ionic composition and transport mechanisms in microbial desalination cells. J. Membr. Sci. 409, $16-23$.

[35] Luo, H., Xu, P., Ren, Z., 2012b. Long-term performance and characterization of microbial desalination cells in treating domestic wastewater. Bioresour. Technol. 120, 187-193.

[36] Luo, H., Xu, P., Roane, T.M., Jenkins, P.E., Ren, Z., 2012c. Microbial desalination cells for improved performance in wastewater treatment, electricity production, and desalination. Bioresour. Technol. 105, 60-66.

[37] Luo, T., Abdu, S., Wessling, M., 2018. Selectivity of ion exchange membranes: A review. J. Membr. Sci. 555, 429-454.

[38] Ma, D., Forrestal, C., Ji, M., Li, R., Ma, H., Ren, Z.J., 2015. Membrane configuration influences microbial capacitive desalination performance. Environ. Sci.: Water Res. Technol. 1(3), 348-354.

[39] Mikhaylin, S., Bazinet, L., 2016. Fouling on ion-exchange membranes: Classification, characterization and strategies of prevention and control. Adv. Colloid Interface Sci. 229, 34-56.

[40] Miller, S., Shemer, H., Semiat, R., 2015. Energy and environmental issues in desalination. Desalination. 366, 2-8.
[41] Nikhil, G., Yeruva, D.K., Mohan, S.V., Swamy, Y., 2016. Assessing potential cathodes for resource recovery through wastewater treatment and salinity removal using non-buffered microbial electrochemical systems. Bioresour. Technol. 215, 247-253.

[42] Peñate, B., García-Rodríguez, L., 2012. Current trends and future prospects in the design of seawater reverse osmosis desalination technology. Desalination. 284, 1-8.

[43] Ping, Q., Cohen, B., Dosoretz, C., He, Z., 2013. Long-term investigation of fouling of cation and anion exchange membranes in microbial desalination cells. Desalination. 325, 48-55.

[44] Ping, Q., Huang, Z., Dosoretz, C., He, Z., 2015. Integrated experimental investigation andmathematical modeling of brackish water desalination and wastewater treatment inmicrobial desalination cells. Water Res. 77, 13-23.

[45] Ping, Q., Porat, O., Dosoretz, C.G., He, Z., 2016. Bioelectricity inhibits back diffusion from the anolyte into the desalinated stream in microbial desalination cells. Water Res. 88, 266-273.

[46] Ping, Q., Zhang, C., Chen, X., Zhang, B., Huang, Z., He, Z., 2014. Mathematical model of dynamic behavior of microbial desalination cells for simultaneous wastewater treatment and water desalination. Environ. Sci. Technol. 48(21), 13010-13019.

[47] Post, J.W., Hamelers, H.V., Buisman, C.J., 2009. Influence of multivalent ions on power production from mixing salt and fresh water with a reverse electrodialysis system. J. Membr. Sci. 330(1-2), 65-72.

[48] Qu, Y., Feng, Y., Wang, X., Liu, J., Lv, J., He, W., Logan, B.E., 2012. Simultaneous water desalination and electricity generation in a microbial desalination cell with electrolyte recirculation for $\mathrm{pH}$ control. Bioresour. Technol. 106, 89-94.

[49] Sophocleous, M., 2004. Global and regional water availability and demand: prospects for the future. Nat. Resour. Res. 13(2), 61-75.

[50] Strathmann, H., 2004. Ion-exchange membrane separation processes. Elsevier.

[51] Wen, Q., Zhang, H., Chen, Z., Li, Y., Nan, J., Feng, Y., 2012. Using bacterial catalyst in the cathode of microbial desalination cell to improve wastewater treatment and desalination. Bioresour. Technol. $125,108-113$.

[52] Zhang, H., Wen, Q., An, Z., Chen, Z., Nan, J., 2016. Analysis of longterm performance and microbial community structure in bio-cathode microbial desalination cells. Environ. Sci. Pollut. Res. 23(6), 5931 5940.

[53] Zhao, N., Wang, H., He, Z., Yan, Q., 2019. Ammonia removal and recovery from diluted forward osmosis draw solution by using a tubular microbial desalination cell. Environ. Sci.: Water Res. Technol. 5(2), 224-230.

[54] Zuo, K., Liu, F., Ren, S., Zhang, X., Liang, P., Huang, X., 2016. A novel multi-stage microbial desalination cell for simultaneous desalination and enhanced organics and nitrogen removal from domestic wastewater. Environ. Sci.: Water Res. Technol. 2(5), 832837.

[55] Zuo, K., Yuan, L., Wei, J., Liang, P., Huang, X., 2013. Competitive migration behaviors of multiple ions and their impacts on ionexchange resin packed microbial desalination cell. Bioresour. Technol. 146, 637-642. 